\title{
Determination of color-changing effects of bleaching chemicals on some heat-treated woods
}

\author{
Memiş Akkuş ${ }^{*}$ (ID and Mehmet Budakçı
}

\begin{abstract}
The aim of this study was to use bleaching chemicals to remove the discoloration occurring on the surface of wood after heat treatment in order to restore the natural color of the wood. For this purpose, samples prepared from Scots pine (Pinus sylvestris L.), sessile oak (Quercus petraea L.), Eastern beech (Fagus orientalis L.), and Uludağ fir (Abies bornmuelleriana Mattf.) were exposed to heat treatment at temperatures of 140 and $160^{\circ} \mathrm{C}$ for time periods of 3,5 , and 7 h. Bleaching solutions $\mathrm{S} 1\left(\mathrm{NaOH}+\mathrm{H}_{2} \mathrm{O}_{2}\right), \mathrm{S} 2\left(\mathrm{NaSiO}_{3}+\mathrm{H}_{2} \mathrm{O}_{2}\right)$, and $\mathrm{S} 3\left(\mathrm{H}_{2} \mathrm{C}_{2} \mathrm{O}_{4}\right)$ at a concentration of $18 \%$ were then applied to the surface of the materials and the color change was determined according to ASTM D 2244 standard. Depending on the heat treatment temperature and duration, an increase in total color change values was detected on the surfaces of the materials and the color of the samples became darker. The total color change values decreased after bleaching with the $\mathbf{S} 2$ solution in the heat-treated Scots pine and fir samples, with the S3 solution in the beech samples, and with the S1, S2, and S3 solutions in the oak samples. The findings showed that by using bleaching chemicals to lighten wood materials darkened after heat treatment, it is possible to obtain results close to the natural color values.
\end{abstract}

Keywords: Wood material, Heat treatment, Bleaching, Color measurement

\section{Introduction}

Although wood materials exhibit adequate natural resistance to some external influences, wood cannot maintain long-term tolerance against the outdoor environment. For this reason, wood materials are impregnated with preservatives or coated with a protective layer [1]. Due to the fact that the solvent-based protective coating products and traditional wood impregnation chemicals threaten the environment and human health, scientific research has focused on new environmentally friendly chemicals and methods and new products for wood protection. As a result of developing technology, protecting wooden materials with impregnation products and chemicals (including toxic substances) has either been limited or completely banned [2-4].

*Correspondence: memisakkus@duzce.edu.tr

Faculty of Technology, Department of Wood Products Industrial

Engineering, Duzce University, 81620 Duzce, Turkey
Heat treatment of wooden material in Europe, and more recently in North America has attracted attention as an environmentally friendly wood protection method. Heat treatment is a physical process that results in permanent changes in the chemical composition of the polymer components of wood cell wall [5]. Heat treatment of wood was researched in Germany for the first time by Stamm and Hansen in the 1930s. Other studies on the subject were conducted in the United States by White in the 1940s and Bavendam, Rundel, and Buro in the 1950s. Kollman and Schneider published their findings in the 1960s and Rusche and Burmester did so in the 1970. In the 1990s, research was carried out in France and the Netherlands [6]. In recent years, different commercial heat treatment processes have emerged: the Finnish process (ThermoWood) uses steam, the Dutch (Plato Wood) uses a combination of steam and heated air, the French (Rectification) uses an inert gas, and the German (OHT) uses heated oil [7]. Therefore, the thermal process of
Springer Open (c) The Author(s) 2020. This article is licensed under a Creative Commons Attribution 4.0 International License, which permits use, sharing, adaptation, distribution and reproduction in any medium or format, as long as you give appropriate credit to the original author(s) and the source, provide a link to the Creative Commons licence, and indicate if changes were made. The images or other third party material in this article are included in the article's Creative Commons licence, unless indicated otherwise in a credit line to the material. If material is not included in the article's Creative Commons licence and your intended use is not permitted by statutory regulation or exceeds the permitted use, you will need to obtain permission directly from the copyright holder. To view a copy of this licence, visit http://creativeco mmons.org/licenses/by/4.0/. 
modification has been applied to improve and change the properties of wood for a long time. ThermoWood technology can be used for an extensive range of applications including garden fences, sauna furnishings, window frames, cladding, and decking [8].

The heat treatment process for wood modification has both the advantage of being evaluated as an environmentally friendly method and the disadvantage of reducing the durability of the wooden material. Deepening the color of the wood and negative after-effects on the gloss and hardness are also among the disadvantages of heat treatment modification [2, 9-11].

Sundqvist [12] performed heat treatment on Scots pine (Pinus sylvestris), Norway spruce (Picea abies), and birch (Betula pubescens) at temperatures of $65-95^{\circ} \mathrm{C}$ for 0-6 days. As a result of the process, pine treated at $65^{\circ} \mathrm{C}$ and $80^{\circ} \mathrm{C}$ showed a red-yellow shift in the sapwood and a yellow-red shift in the heartwood. The color homogeneity was less for birch sapwood than for pine and spruce, and the homogeneity generally tended to decrease with increasing treatment temperature. According to Sehlstedt-Persson [13], the main reason for the color changes in the sapwoods of pine and spruce exposed to heat treatment at $60{ }^{\circ} \mathrm{C}-95^{\circ} \mathrm{C}$ arose from the compounds in the extractives of the materials. The color changes of the woods and extractives caused by heat treatment increased with increasing time and temperature. Tomak et al. [14] reported that red color values increased on all heat-treated wood material surfaces and that the coniferous species were more reddish than deciduous species. They stated that as a result of heat treatment, darker tones were dominant on all wood material surfaces because of the different amounts of lignin and hemicellulose content found in the wood materials used.

Each type of wood has its own variation of color, texture, and grain pattern. Some cuts of solid wood and flitches of veneer may be lighter or darker than others. To obtain a uniform color in furniture, the wood is either bleached or dyed. In other words, the only way to avoid this discoloration is to bleach the wood or use a bleaching toner on the wood before finishing. Bleaching is the removing of color pigments in the structure of wood using various bleaching chemicals and bleaching systems. While there are many bleaching agents available, the two most commonly used chemicals are sodium hydroxide $(\mathrm{NaOH})$ and hydrogen peroxide $\left(\mathrm{H}_{2} \mathrm{O}_{2}\right)$ [15] Liang and Wang [16] found that peracetic acid had no effect on the structure of birch veneer samples, and that hydrogen peroxide and sodium hypochlorite bleaching chemicals removed some of the lignin from the coating surface. Yamamoto et al. [17], in their study examining color change values, in order to reduce the use of resin and improve the bonding resistance, treated birch veneers at $80{ }^{\circ} \mathrm{C}$ with $5 \% \mathrm{H}_{2} \mathrm{O}_{2}, 5 \% \mathrm{H}_{2} \mathrm{O}_{2}+$ alkali $(1.4 \%$ sodium hydroxide $+5 \%$ sodium silicate $+0.5 \%$ magnesium sulfate), and water. As a result, they reported that the veneer surfaces were significantly whiter, resulting in a decrease in the yellow and red color values while increasing the color brightness value. Mononen et al. [18] in their study, treated ordinary birch (Betula pendula Roth) wood with $\mathrm{H}_{2} \mathrm{O}_{2}$ solution and determined the color and chemical changes that occurred. As a result of the study, they stated that there was a significant increase in whiteness, whereas the red color value decreased and the yellow color value increased. Chemical analysis of the birch samples treated with $\mathrm{H}_{2} \mathrm{O}_{2}$ indicated an increase in unconjugated carbonyl structures and a simultaneous degradation of aromatic structures. Budakci and Karamanoglu [19] in their study, applied bleaching chemicals, including $18 \%$ concentrations of $\mathrm{S} 1\left(\mathrm{NaOH}+\mathrm{H}_{2} \mathrm{O}_{2}\right)$, S2 $\left(\mathrm{NaOH}+\mathrm{Ca}(\mathrm{OH})_{2}\right), \quad \mathrm{S} 3 \quad\left(\mathrm{KMnO}_{4}+\mathrm{NaHSO}_{3}+\mathrm{H}_{2} \mathrm{O}_{2}\right)$, S4 $\left(\mathrm{NaSiO}_{3}+\mathrm{H}_{2} \mathrm{O}_{2}\right)$, and the commercial product $\mathrm{S} 5$ [Cuprinol Decking Restorer- $\left(\mathrm{H}_{2} \mathrm{C}_{2} \mathrm{O}_{4}+\mathrm{C}_{2} \mathrm{H}_{4}(\mathrm{OH})_{2}\right.$ ] to samples of pine, Eastern beech, oak and chestnut that had been exposed to a 12-month aging process. At the end of the application, the highest color change value was obtained on the pine, beech and chestnut surfaces with the $\mathrm{S} 4\left(\mathrm{NaSiO}_{3}+\mathrm{H}_{2} \mathrm{O}_{2}\right)$ solution and on the oak surfaces with the S1 solution. Cheumani-Yona et al. [20] carried out the bleaching of liquefied black poplar wood with hydrogen peroxide. After the bleaching process, they found a remarkable increase in the color parameters $L^{*}$ $a^{*} b^{*}$ and $\Delta E^{*}$.

The objective of this study was to use bleaching chemicals to remove the discoloration occurring on the surface of wooden material after heat treatment in order to restore the natural color to the surface of the wood.

\section{Materials and methods Wood materials}

Scots pine (Pinus sylvestris L.), sessile oak (Quercus petraea L.), Eastern beech (Fagus orientalis L.), and Uludağ fir (Abies bornmuelleriana Mattf.), which are widely used in the furniture and decoration industry in Turkey, were chosen for this study. Samples were randomly selected from the sapwood section of first-grade timber, and all exhibited regular-fiber, with no variation in color or density, were knotless and crack-free, had annual rings perpendicular to the surface, and were cut to dimensions of $18 \times 110 \times 350 \mathrm{~mm}$, with regard to the principles in TS $2470[21]$.

\section{Heat treatment}

The air-dried samples were first kept at $103 \pm 2{ }^{\circ} \mathrm{C}$ until they reached a constant weight. They were then exposed to heat treatment at temperatures of $140{ }^{\circ} \mathrm{C}$ and $160{ }^{\circ} \mathrm{C}$ 
for 3, 5, and $7 \mathrm{~h}$. Subsequently, they were stored in an air-conditioned cabinet at $20 \pm 2{ }^{\circ} \mathrm{C}$ and $65 \pm 5 \%$ relative humidity until a constant weight was reached.

\section{Bleaching chemicals}

Sodium hydroxide $(\mathrm{NaOH})$, sodium silicate $\left(\mathrm{NaSiO}_{3}\right)$, hydrogen peroxide $\left(\mathrm{H}_{2} \mathrm{O}_{2}\right)$, and oxalic acid $\left(\mathrm{H}_{2} \mathrm{C}_{2} \mathrm{O}_{4}\right)$ were used in the bleaching procedure shown in Table 1 as three different solution groups.

\section{Application of the bleaching process}

The chemical substances used for bleaching, depending on their properties, were prepared at $18 \%$ concentration by weight $\left(M_{\mathrm{g}}\right)$ or by volume $\left(V_{\mathrm{ml}}\right)$ [22]. For this purpose the following Eqs. (1), (2) were used:

$$
\begin{aligned}
& \text { For the solid form : } M g=\frac{M_{\mathrm{s}} \cdot \% \frac{M}{M}}{\% S}, \\
& \text { For the liquid form : } V_{\mathrm{mL}}=\frac{V_{s} \cdot \% \frac{V}{V}}{\% S . d},
\end{aligned}
$$

where $M_{\mathrm{g}}$ is the amount of the desired solution (g); $M_{\mathrm{s}}$, the amount of the solution for the desired preparation; $\% S$, the impurity rate of the substance; $V_{\mathrm{mL}}$, the amount of the desired solution $(\mathrm{mL}) ; V_{\mathrm{s}}$, the amount of the solution for the desired preparation; $V / V$, the percentage by volume for the desired solution, and $d$ is the density of the solution.

The prepared chemicals were applied with a sponge to the surface of the heat-treated samples, first parallel, then perpendicular, and then again parallel to the fibers at $100 \pm 10 \mathrm{~mL} / \mathrm{m}^{2}$. Constitutive chemical solutions of different combinations were individually applied to the wood surfaces at 3-min intervals in order to allow interaction of the previously applied chemicals with the wood.

To improve the perpendicular penetration, after bleaching, the treated wood samples were allowed to dry at room temperature for 2 days, and then the neutralization process was performed with distilled water. Finally, the moisture content of the samples was adjusted to $12 \%$ and the sample surfaces were sandpapered slightly before taking the experimental measurements.

\section{Color measurement}

Color measurements were performed according to the ASTM D 2244 [23] using the BYK Gardner SpectroGuide 45/0 at Duzce University. The 1976 International Commission on Illumination (Commission Internationale de I'Eclairage-CIE) system was used for measuring the $L^{*}, a^{*}$, and $b^{*}$ color coordinates. The three CIE $L^{*} a^{*} b^{*}$ coordinates representing the lightness of the colors $L^{*}$ [from $0 \%$ (black) to $100 \%$ (white)], $a^{*}$ [from red (+) to green $(-)$ ], and $b^{*}[$ from yellow $(+)$ to blue $(-)$ ] were calculated automatically using Datacolor Quality software (Fig. 1). The $L^{*}, a^{*}$, and $b^{*}$ values were used to calculate the color changes $\Delta L^{*}, \Delta a^{*}$, and $\Delta b^{*}$. Finally, the total color change $\left(\Delta E^{*}\right)$ was calculated using Eq. (3). Before performing the color measurements, the device was calibrated to $a=-1.00 \pm 0.3 ; b=0.58 \pm 0.3 ; L=94.95 \pm 0.3$ $[19,24]$ :

$$
\Delta E^{*}=\sqrt{\left(\Delta a^{*}\right)^{2}+\left(\Delta b^{*}\right)^{2}+\left(\Delta L^{*}\right)^{2}}
$$

where $\Delta L^{*}$ is $L_{\mathrm{h}}{ }^{*}-L_{\mathrm{c}}{ }^{*}, \Delta a^{*}$ is $a_{\mathrm{h}}{ }^{*}-a_{\mathrm{c}}{ }^{*}, \Delta b^{*}$ is $b_{\mathrm{h}}{ }^{*}-b_{\mathrm{c}}$; ; is the untreated control sample, and ${ }_{\mathrm{h}}$ is the heat-treated sample; where $\Delta L^{*}$ is $L_{\mathrm{s}}{ }^{*}-L_{\mathrm{c}}{ }^{*}, \Delta a^{*}$ is $a_{\mathrm{s}}{ }^{*}-a_{\mathrm{c}}{ }^{*}, \Delta b^{*}$ is $b_{\mathrm{s}}{ }^{*}-$ $b_{\mathrm{c}}{ }^{*}{ }_{\mathrm{c}}$ is the untreated control sample, and $\mathrm{s}$ is the bleached sample after the heat treatment process.

\section{Evaluation of data}

In the study, the $\Delta a^{*}, \Delta b^{*}, \Delta L^{*}$ and $\Delta E^{*}$ color change values of the untreated samples (controls) and heat-treated

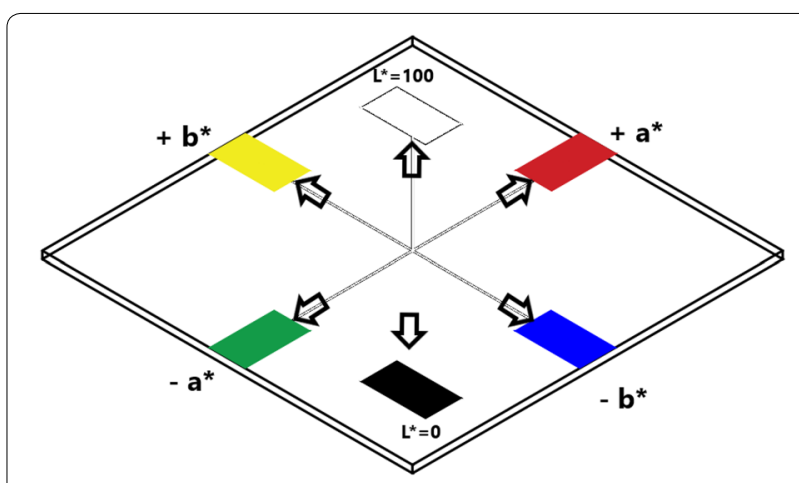

Fig. $1 \mathrm{ClE} L^{*} a^{*} b^{*}$ color system

Table 1 Solution groups used in bleaching process on the surfaces of wood

\begin{tabular}{llccc}
\hline Solution groups & Chemicals & pH level & Chemical amount to be applied $\left(\mathbf{m L} / \mathbf{m}^{\mathbf{2}}\right)$ & Neutralization agent \\
\hline S1 & $\mathrm{NaOH}+\mathrm{H}_{2} \mathrm{O}_{2}$ & 12.04 & $100 \pm 10$ & Distilled water \\
S2 & $\mathrm{NaSiO}_{3}+\mathrm{H}_{2} \mathrm{O}_{2}$ & 10.05 & & \\
S3 & $\mathrm{H}_{2} \mathrm{C}_{2} \mathrm{O}_{4}$ & 1.4 & & \\
\hline
\end{tabular}


samples, were statistically compared with those of the samples bleached after heat treatment using the statistical package program. As a result of the analysis of variance (ANOVA) multiple-factor analysis, the bleaching effect of the wood species, the solution group, the heat treatment temperature, and the duration of heat treatment on the wooden material were determined. Comparisons were made via Duncan analysis and LSD (least significant difference).

\section{Results and discussion}

\section{Color changes of Scots pine}

Table 2 shows the $\Delta a^{*}, \Delta b^{*}, \Delta L^{*}$, and $\Delta E^{*}$ color change results for Scots pine samples subjected to heat treatment and the heat-treated samples after bleaching treatment.

According to Table 2, the maximum difference in the red color value $\left(\Delta a^{*}\right)$ was determined as 7.01 for the Scots pine samples heat-treated at $160{ }^{\circ} \mathrm{C}$ for $7 \mathrm{~h}$ and the minimum as 3.68 in those treated at $140{ }^{\circ} \mathrm{C}$ for $5 \mathrm{~h}$ (Fig. 2). When Table 2 is examined, the S1 and S2 bleaching solutions applied to the heat-treated Scots pine samples are seen to cause the red color value of the material to decrease and the results are close to the natural red color value of Scots pine. Within the scope of the study, the S3 solution caused the red color value of heat-treated Scots pine to increase more. It has been stated in the literature that heat treatment lowers the $\mathrm{pH}$ value of wood, leading to a more acidic structure and as a result, increasing the red color value of the material [25]. In this context, it was concluded that there was an inverse relationship between the $\mathrm{pH}$ of the wood material and the color darkening. The acidic structure of S3 used as a bleaching solution could be seen as the reason for the increase in the red color value.

The maximum difference in the yellow color value $\left(\Delta b^{*}\right)$ was found as 8.20 in the samples heat-treated at $160^{\circ}$ for $7 \mathrm{~h}$ and the minimum as 5.07 in the samples heat-treated at $160^{\circ}$ for $3 \mathrm{~h}$ (Table 2). Tomak et al. [13] stated that the yellow color value of Scots pine increased after heat treatment. They emphasized that this could be caused by formation of secondary products in the wood material as a result of the heat treatment and/or decomposition due to the release of quinone and quinonemethide. All the bleaching solutions applied to the Scots pine surfaces after heat treatment resulted in a decrease in the yellow color value. However, the S2 and S3 solutions were more effective in decreasing the yellow color value than the S1 solution. Therefore, it was observed that application of the S2 and S3 solutions gave results closer to the natural yellow color value of the material (Fig. 3).

According to Table 2, the maximum difference in the lightness value $\left(\Delta L^{*}\right)$ in the Scots pine was obtained as -20.31 in the samples heat-treated at $160{ }^{\circ} \mathrm{C}$ for $7 \mathrm{~h}$, while the minimum was found as -9.22 in those treated at $140^{\circ} \mathrm{C}$ for 3 and $5 \mathrm{~h}$. In the literature, it is reported that the lightness value of Scots pine decreased after heat treatment [14]. When Table 2 is examined, it can be seen that the lightness value of the Scots pine tended to decrease after application of the S1 and S3 bleaching solutions, while with the S2 solution application it increased.

The maximum total color change value $\left(\Delta E^{*}\right)$ of the Scots pine was determined as 23.01 in the samples heattreated at $160{ }^{\circ} \mathrm{C}$ for $7 \mathrm{~h}$, and the minimum as 12.46 at $140{ }^{\circ} \mathrm{C}$ for $5 \mathrm{~h}$ (Fig. 2). In the literature, it was stated that, as a result of heat treatment, redness, yellowness, and total color change values in Scots pine increased, while the lightness value was reduced [14]. It has been reported that higher drying temperatures lead not only to color changes and darkening of wood but also to an increase of resin flow, especially around knots in pine. We have observed the resin flow from the surfaces of pine after heat treatment processes [13]. According to Tarvainen et al. [26], color change in pine heartwood increases markedly at drying temperatures exceeding $70{ }^{\circ} \mathrm{C}$, probably depending on the resin content. Pine sap also plays an important role in color change of pine wood surfaces after heat treatment. It is thought that these by-products formed in the material as a result of heat treatment interact with the lightening chemicals and affect the total color change values. In the study, the highest total color change value (21.70) was obtained in the heat-treated Scots pine samples bleached with the S3 solution, while the lowest value (8.03) was obtained in those bleached with the $\mathrm{S} 2$ solution after heat treatment at $140^{\circ} \mathrm{C}$ for $5 \mathrm{~h}$.

However, no significant difference was observed between samples that were bleached with the S2 solution after $5 \mathrm{~h}$ of heat treatment at $140{ }^{\circ} \mathrm{C}$ and those that were bleached with the $\mathrm{S} 2$ solution after heat treatment at $160{ }^{\circ} \mathrm{C}$ for $3 \mathrm{~h}$ or at $160{ }^{\circ} \mathrm{C}$ for $7 \mathrm{~h}(p<0.05)$. In general, the S1 and S3 solutions applied to heat-treated Scots pine surfaces caused an increase in the total color change value while the $\mathrm{S} 2$ solution caused a decrease. This was attributed to the fact that the S2 solution had a low alkaline property.

\section{Color changes of Uludağ fir}

Table 3 shows the statistical comparisons of $\Delta a^{*}, \Delta b^{*}$, $\Delta L^{*}$, and $\Delta E^{*}$ color change results for the fir specimens which were subjected to heat treatment and the heattreated samples after bleaching treatment.

According to Table 3, the maximum difference in the red color value $\left(\Delta a^{*}\right)$ in the fir was 2.80 for the samples exposed to heat treatment at $160^{\circ} \mathrm{C}$ for $5 \mathrm{~h}$, and the minimum as 0.20 in those treated at $140^{\circ} \mathrm{C}$ for $3 \mathrm{~h}$ (Fig. 4). The S1 and S2 bleaching solutions applied to the fir surfaces 


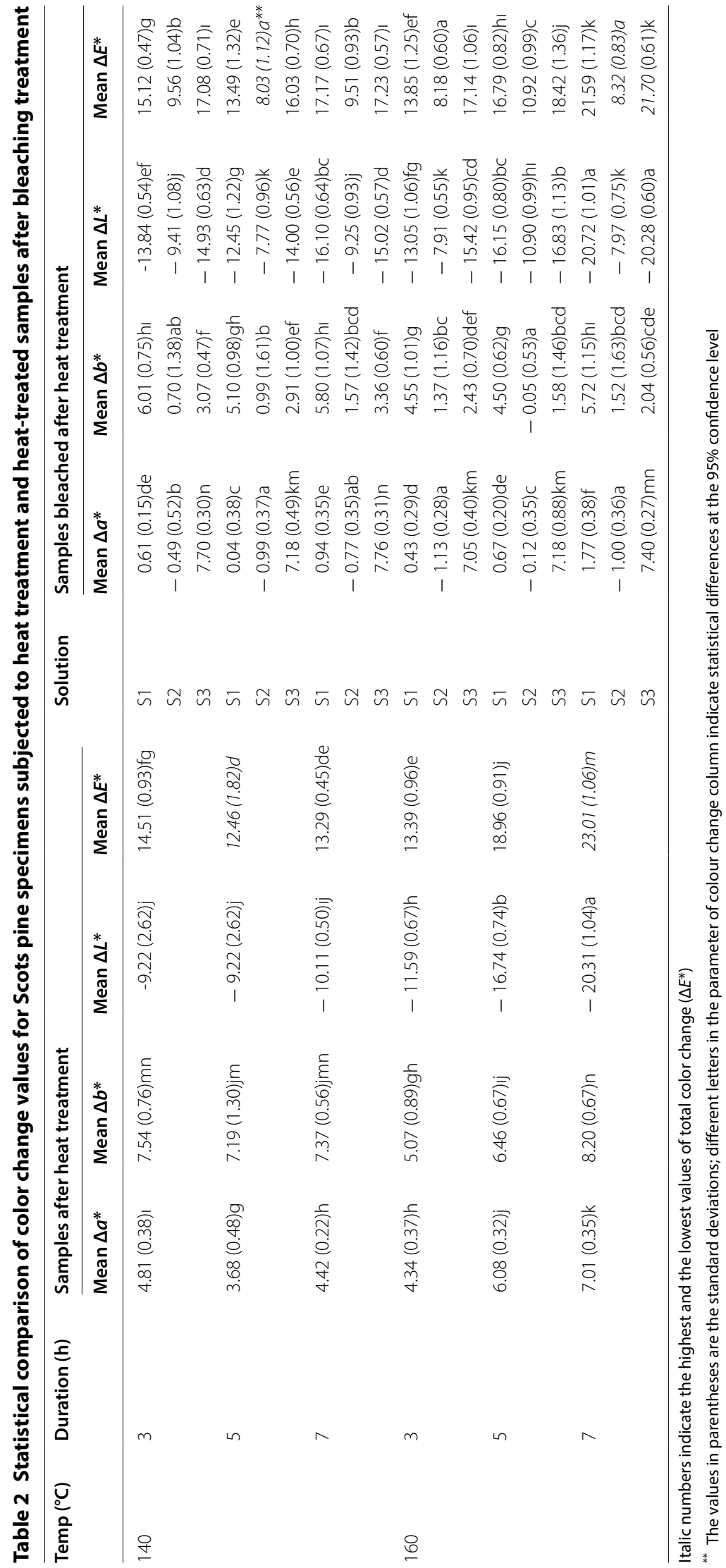




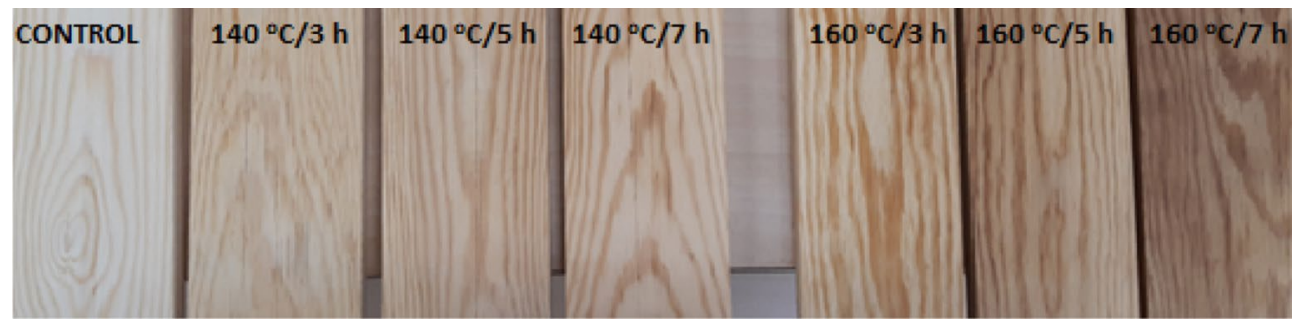

Fig. 2 Color change in Scots pine after heat treatment
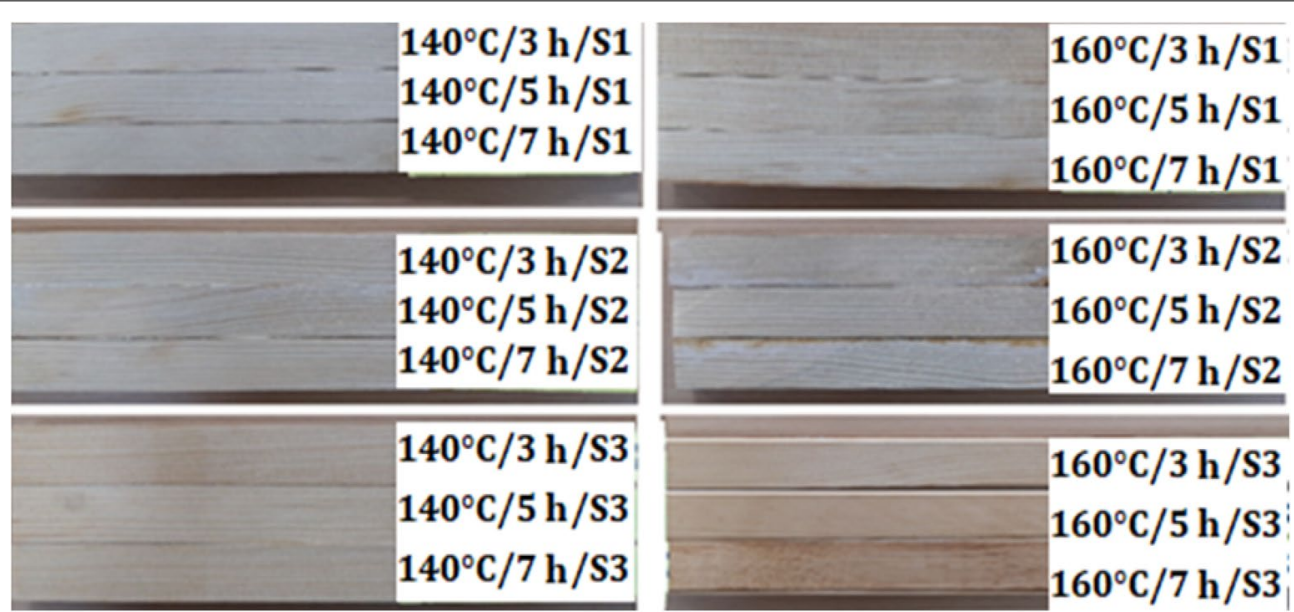

Fig. 3 Heat-treated Scots pine samples after bleaching treatment

after heat treatment had a negative effect on the red color value, while the S3 solution was found to affect it positively. The S1 and S2 solutions caused the heat-treated fir to have a more greenish appearance, while the S3 solution caused the fir to appear more reddish (Fig. 5), as in the Scots pine wood.

In Table 3, the maximum difference in the yellow color value $\left(\Delta b^{*}\right)$ was determined as 6.9 in the samples heattreated at $140{ }^{\circ} \mathrm{C}$ for $7 \mathrm{~h}$, and the minimum as 1.05 in those treated at $160{ }^{\circ} \mathrm{C}$ for $3 \mathrm{~h}$. In the fir samples, after the heat treatment, the $\mathrm{S} 2$ solution generally had a negative effect on the yellow color value, while the S1 and S3 solutions had a positive effect on the yellow color value. Thus, the S1 and S3 solutions caused the fir to appear more yellowish in color. The closest result to the natural yellow color value (-0.30) was obtained with the S2 solution on the fir surfaces heat-treated at $140{ }^{\circ} \mathrm{C}$ for $7 \mathrm{~h}$.

According to Table 3, the maximum difference in the lightness value $\left(\Delta L^{*}\right)$ in the fir was obtained as -9.1 in the samples heat-treated at $160{ }^{\circ} \mathrm{C}$ for $5 \mathrm{~h}$, and the minimum as -4.69 in those treated at $140{ }^{\circ} \mathrm{C}$ for $5 \mathrm{~h}$. It was observed that the lightness value decreased in all heat treatment variations applied to the fir. The S1 and S3 bleaching solutions applied after heat treatment generally reduced the lightness value, while the S2 solution increased it. Bleaching with the application of the $\mathrm{S} 2$ solution to the fir specimens subjected to heat treatment at $160{ }^{\circ} \mathrm{C}$ for $3 \mathrm{~h}$ gave the lightness value closest to the natural (untreated) samples.

The maximum total color change value $\left(\Delta E^{*}\right)$ in the fir wood was determined as 11.10 in the samples heattreated at $160{ }^{\circ} \mathrm{C}$ for $5 \mathrm{~h}$, and the minimum as 6.81 in those treated at $140{ }^{\circ} \mathrm{C}$ for $3 \mathrm{~h}$ (Fig. 4). In many studies, it is stated that as the heat treatment temperature increased, the color of the wood material darkened $[5,8,14,27-29]$. The darkening of wood is one of the most visible effects of heat treatment. This effect is often explained as the result of the formation of colored degradation and oxidation products from hemicelluloses and extractives. The intensity of the discoloration depends on the severity of the treatment [30]. It is stated that heat treatment influences the surface color of different woods to varying extents. This phenomenon is probably related to the volatilization of color extracts as well as to the oxidation of some chemical constituents of wood, including lignin and polysaccharides [31]. 


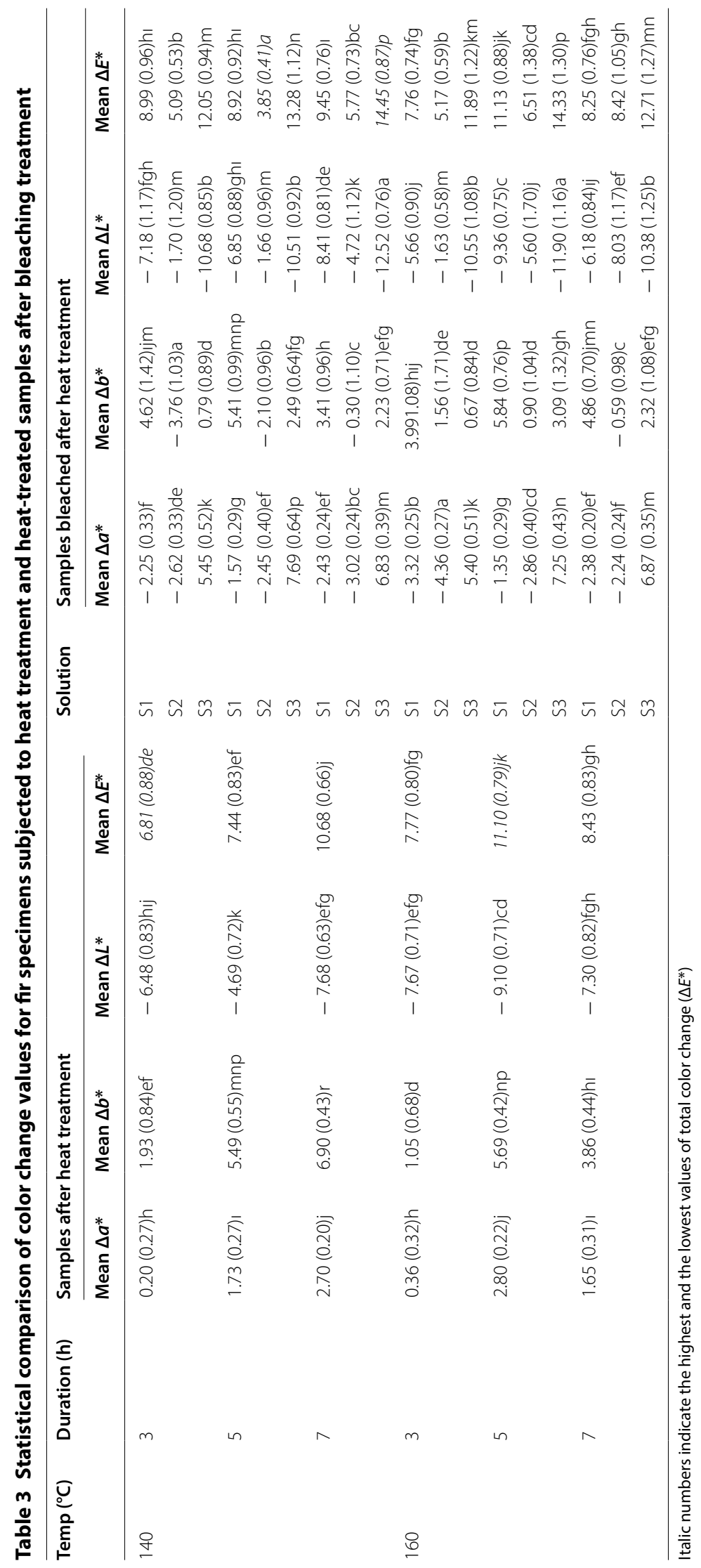




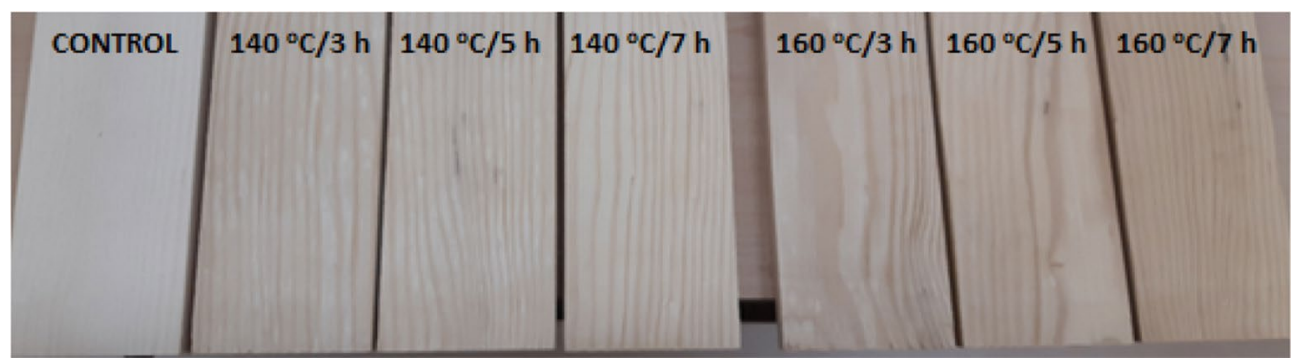

Fig. 4 Color change in fir after heat treatment

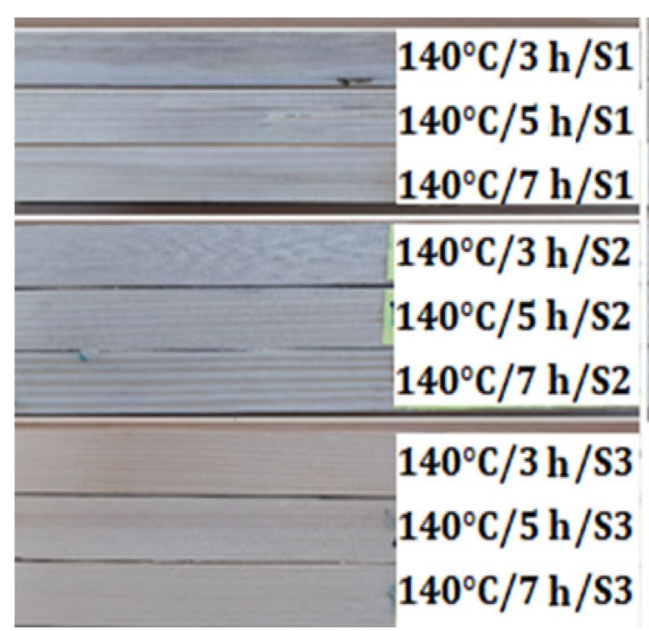

$160^{\circ} \mathrm{C} / 3 \mathrm{~h} / \mathrm{S} 1$

$160^{\circ} \mathrm{C} / 5 \mathrm{~h} / \mathrm{S} 1$

$160^{\circ} \mathrm{C} / 7 \mathrm{~h} / \mathrm{S} 1$

$160^{\circ} \mathrm{C} / 3 \mathrm{~h} / \mathrm{S} 2$

$160^{\circ} \mathrm{C} / 5 \mathrm{~h} / \mathrm{S} 2$

$160^{\circ} \mathrm{C} / 7 \mathrm{~h} / \mathrm{S} 2$

$160^{\circ} \mathrm{C} / 3 \mathrm{~h} / \mathrm{S} 3$

$160^{\circ} \mathrm{C} / 5 \mathrm{~h} / \mathrm{S} 3$

$160^{\circ} \mathrm{C} / 7 \mathrm{~h} / \mathrm{S} 3$

Fig. 5 Heat-treated fir samples after bleaching treatment

In this study, in the samples heat-treated and followed by the bleaching process with the S1 and S3 solutions, the total color change values were found to increase, while they decreased in those bleached with the S2 solution.

For the purpose of the study, the color value closest to the natural fir wood was obtained in samples heattreated at $140{ }^{\circ} \mathrm{C}$ for $5 \mathrm{~h}$ followed by bleaching with the $\mathrm{S} 2$ solution. Bleaching chemicals act on the side compounds of the wood material to lighten the wood material [32, 33]. It is thought that applied chemical bleaching materials can cause color change in materials by affecting the acetic acid, free radicals and extractives released at the end of the heat treatment. In addition, the difference between the total color change values among the solutions and the different $\mathrm{pH}$ values of the solutions used may have been effective. In the literature, it was stated that as a result of the bleaching process using different solution groups, the $\mathrm{Ca}$ $(\mathrm{OH})_{2}+\mathrm{H}_{2} \mathrm{O}_{2}$ solution increased the yellow color values in the samples and that this resulted from the $\mathrm{pH}$ of the bleaching solutions used [34].

\section{Color changes of eastern beech}

Table 4 shows the statistical comparisons of $\Delta a^{*}, \Delta b^{*}$, $\Delta L^{*}$, and $\Delta E^{*}$ color change results for the beech specimens which were subjected to heat treatment and the heat-treated samples after bleaching treatment.

The maximum difference in the red color value $\left(\Delta a^{*}\right)$ of the heat-treated beech was obtained as -1.05 at $160{ }^{\circ} \mathrm{C}$ for $3 \mathrm{~h}$ (Fig. 6). There was no statistically significant difference between heat treatment at $160{ }^{\circ} \mathrm{C}$ for $3 \mathrm{~h}$ or at $160{ }^{\circ} \mathrm{C}$ for $7 \mathrm{~h}(p<0.05)$. The minimum difference in the red color value was found as -0.23 in the samples subjected to heat treatment at $140{ }^{\circ} \mathrm{C}$ for $5 \mathrm{~h}$. In the literature it was emphasized that, although the natural state of beech material is reddish-white, after technical drying, the color changes to a brick-red color [35]. Depending on the heating application method, temperature, and duration, decreases in wood volume and mass are thought to occur as a result of water loss in the wood structure caused by increased fibrillation and the decreased presence of hydroxyl groups, material losses in the cell wall, and hemicellulose disintegration $[3,5]$. The application of the S1 and S2 bleaching solutions 


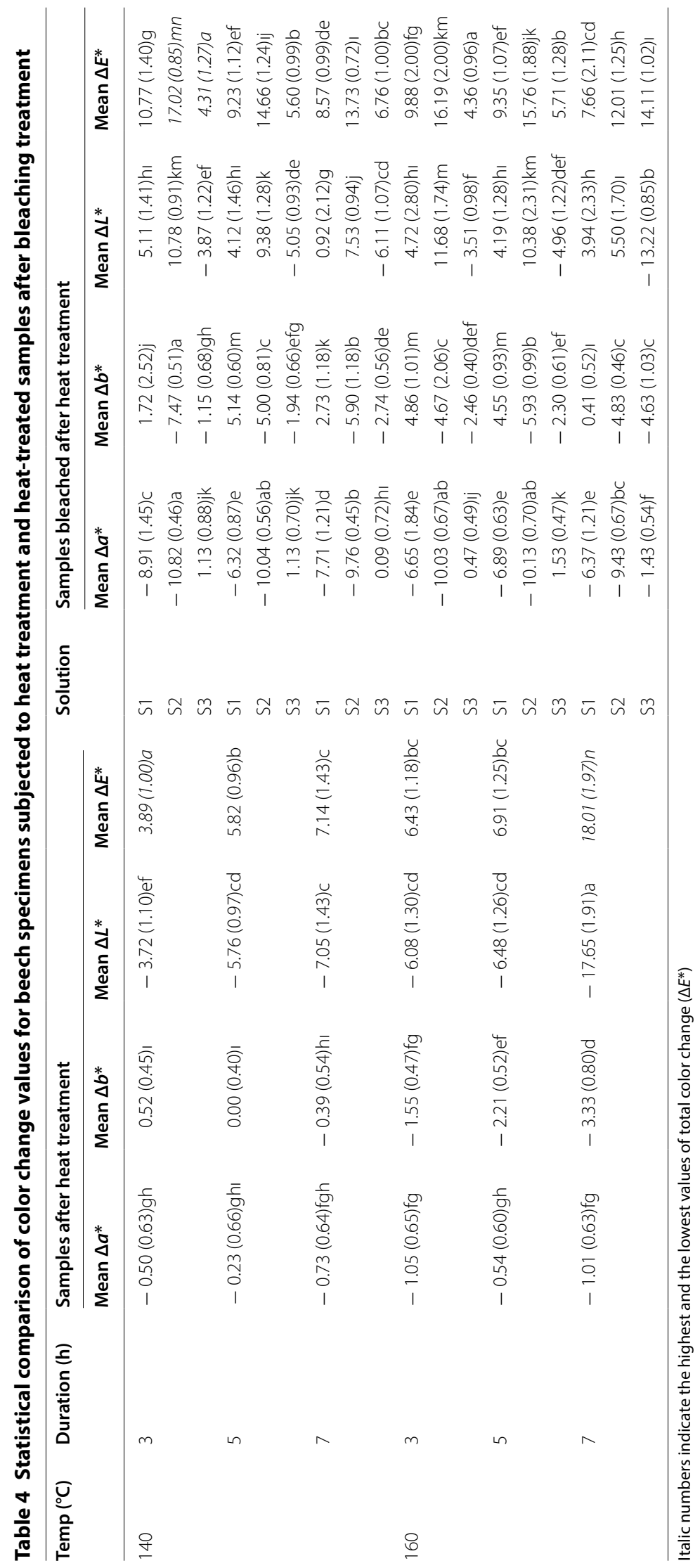




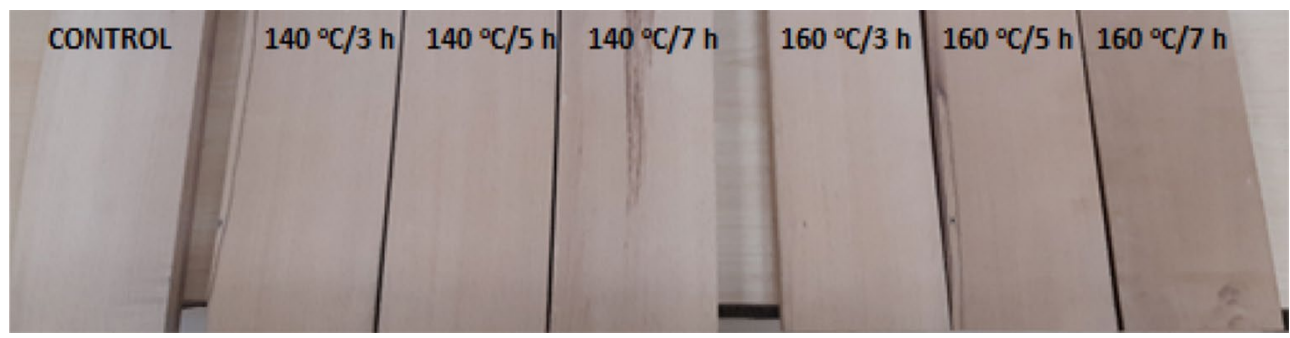

Fig. 6 Color change in beech after heat treatment

to the beech surfaces after heat treatment made them appear more greenish, while the S3 solution achieved values close to the natural red color tone (Fig. 7).

According to Table 4, the maximum difference in the yellow color value $\left(\Delta b^{*}\right)$ in the beech was obtained as -3.33 in the samples heat-treated at $160{ }^{\circ} \mathrm{C}$ for $7 \mathrm{~h}$. No difference (0.00) was detected among the heat-treated samples. In the beech samples subjected to heat treatment followed by bleaching, the S2 and S3 solutions caused a more bluish appearance by negatively affecting the yellow color value, whereas the S3 solution caused a more reddish appearance. It is stated in the literature that application of $5 \% \mathrm{H}_{2} \mathrm{O}_{2}$ on birch veneer surfaces reduced the red color value of the material [17].

The maximum difference in the lightness value $\left(\Delta L^{*}\right)$ for the beech wood was determined as -17.65 in the samples heat-treated at $160{ }^{\circ} \mathrm{C}$ for $7 \mathrm{~h}$, and the minimum as -3.72 in those treated at $140{ }^{\circ} \mathrm{C}$ for $3 \mathrm{~h}$. The $\mathrm{S} 1$ and $\mathrm{S} 2$ solutions had a positive effect on the lightness value of the samples bleached after heat treatment, while the S3 solution had a negative effect.
According to Table 4, the maximum total color change value $\left(\Delta E^{*}\right)$ of the beech was obtained as 18.01 in the samples heat-treated at $160{ }^{\circ} \mathrm{C}$ for $7 \mathrm{~h}$, and the minimum as 3.89 in those treated at $140{ }^{\circ} \mathrm{C}$ for $3 \mathrm{~h}$ (Fig. 6). In the study, as the heat treatment duration and temperature increased, the total color change value in the beech increased in parallel. It is stated that the sap and extractives of beech undergo a clearly visible color change after heat treatment, and lightness $\left(L^{*}\right)$ decreases, saturation $\left(C^{*}\right)$ increases, and the hue $\left(h^{\circ}\right)$ moves towards red. The color changes increase with time and temperature. This might be explained by the formation of colored degradation products deriving from the hydrolysis of hemicelluloses [13]. The S1 and S2 solutions increased the total color change value in all samples subjected to post-heat treatment bleaching except for the samples subjected to heat treatment at $160^{\circ} \mathrm{C}$ for $7 \mathrm{~h}$. The $\mathrm{S} 3$ solution resulted in a general decrease in the total color change value. The S1 and S2 bleaching solutions had an alkaline structure and this was thought to be an important factor in the increase of the total color change value. In the literature, the degradation of hemicellulose, lignin, and some

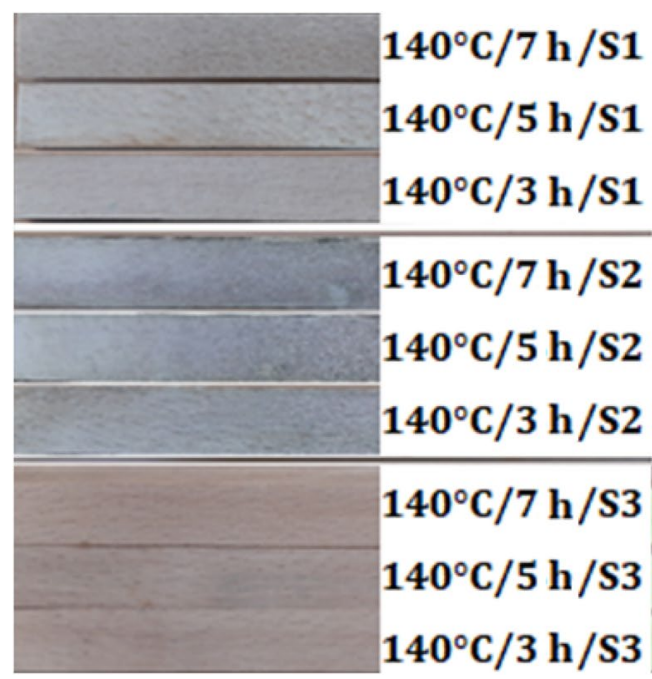

$160^{\circ} \mathrm{C} / 7 \mathrm{~h} / \mathrm{S} 1$

$160^{\circ} \mathrm{C} / 5 \mathrm{~h} / \mathrm{S} 1$

$160^{\circ} \mathrm{C} / 3 \mathrm{~h} / \mathrm{S} 1$

$160^{\circ} \mathrm{C} / 7 \mathrm{~h} / \mathrm{S} 2$.

$160^{\circ} \mathrm{C} / 5 \mathrm{~h} / \mathrm{S} 2$

$160^{\circ} \mathrm{C} / 3 \mathrm{~h} / \mathrm{S} 2$

$160^{\circ} \mathrm{C} / 7 \mathrm{~h} / \mathrm{S} 3$

$160^{\circ} \mathrm{C} / 5 \mathrm{~h} / \mathrm{S} 3$

$160^{\circ} \mathrm{C} / 3 \mathrm{~h} / \mathrm{S} 3$

Fig. 7 Heat-treated beech samples after bleaching treatment 
extractives in heat-treated wood is mentioned as the cause of color changes [36]. Substances such as quinone and quinone methide released in the wood material after the decomposition of these compounds interact according to the structure and $\mathrm{pH}$ values of the chemicals used and affect the total color change of the material. In a different study, birch veneer samples were treated with peracetic acid, hydrogen peroxide and sodium hypochlorite chemicals. According to the results, the peracetic acid did not cause any effect on the structure of the wood, whereas the alkaline hydrogen peroxide and sodium hypochlorite chemicals removed some of the lignin on the birch veneer surface [16].

\section{Color changes of sessile oak}

Table 5 shows the statistical comparisons of the $\Delta a^{*}$, $\Delta b^{*}, \Delta L^{*}$, and $\Delta E^{*}$ color change results for the oak samples that were subjected to heat treatment and the heattreated samples after bleaching treatment.

According to Table 5 , the maximum difference in the red color value $\left(\Delta a^{*}\right)$ for the oak was determined as 2.08 in the samples heat-treated at $160{ }^{\circ} \mathrm{C}$ for $7 \mathrm{~h}$, and the minimum as 0.14 in those treated at $140{ }^{\circ} \mathrm{C}$ for $5 \mathrm{~h}$ (Fig. 8). The S1 and S2 bleaching solutions applied to the oak surfaces after heat treatment reduced the red color value negatively and created a more greenish appearance (Fig. 9). On the other hand, as in the pine and fir, the S3 solution increased the difference in the red color value for the oak.

In the oak, the maximum difference in the yellow color value $\left(\Delta b^{*}\right)$ was found as 2.36 in the samples heat-treated at a $140{ }^{\circ} \mathrm{C}$ for $7 \mathrm{~h}$. There was no difference in the samples heat-treated at $160{ }^{\circ} \mathrm{C}$ for $3 \mathrm{~h}$ when compared to the natural (untreated) samples. The S1 bleaching solution applied to the oak surfaces after heat treatment had a positive effect on the yellow color value difference, while the S2 and S3 solutions had a negative effect. In the study, the result closest to the yellow color value of the oak material was obtained from the samples bleached with the S3 solution (Fig. 9).

When Table 5 is examined, the maximum difference in the lightness value $\left(\Delta L^{*}\right)$ for the oak is found as -18.55 in the samples that were heat-treated at $160{ }^{\circ} \mathrm{C}$ for $7 \mathrm{~h}$, while the minimum difference can be seen as -2.76 in the samples exposed to heat treatment at $140{ }^{\circ} \mathrm{C}$ for $5 \mathrm{~h}$. In general, the results closest to the lightness value of natural (untreated) oak were recorded in the samples treated with the S1 and S2 solutions. The S3 solution negatively affected the lightness value.

The maximum total color change value $\left(\Delta E^{*}\right)$ of the oak wood was recorded as 18.72 in the samples heat-treated at $160{ }^{\circ} \mathrm{C}$ for $7 \mathrm{~h}$, and the minimum as 8.03 in those treated at $140{ }^{\circ} \mathrm{C}$ for $3 \mathrm{~h}$. In the study, it was determined that the increase in the total color change value was related to the increase of heat treatment temperature and duration. The specimens became darker with increasing treatment time and temperature, as reported by several authors [37, 38]. Esteves et al. [39] reported that noticeable color changes could already be obtained for small mass losses of $2-4 \%$, but the effect depended on the extent of treatment and was related to the chemical composition of the heat-treated woods. The darker tonality of heat-treated wood is often attributed to the formation of colored degradation products from hemicelluloses and to extractives that seem to participate in the color formation of heat-treated wood [40]. It is reported that FTIR analysis showed degradation of cell wall polymers resulting in the generation of structures which are responsible for the color darkening of thermally modified wood [31]. The highest total color change value (13.42) was obtained in the samples treated with the $\mathrm{S} 2$ solution following heat treatment at $140{ }^{\circ} \mathrm{C}$ for $5 \mathrm{~h}$, while the lowest value (6.67) was in samples treated with the S1 solution after heat treatment at $160{ }^{\circ} \mathrm{C}$ for $5 \mathrm{~h}$. In general, it was found that all the bleaching solutions applied to the surface of the heat-treated oak wood decreased the total color change value of the material. Although the arithmetic average of the total color change values for the heat-treated oak wood was 10.4, as a result of the application of the S1 solution it fell to 7.46, with the S2 solution to 9.95, and with the S3 solution to 8.32.

\section{Conclusions}

In this study, the aim was to use S1, S2, and S3 bleaching solutions to remove the negative color changes occurring in the Scots pine, fir, beech and oak woods from the effect of heat treatment. The goal was to achieve values close to the natural colors of the wood materials used in the experiments.

- The greatest red color change in the study occurred in the Scots pine. The red color change increased positively in the fir, Scots pine, and oak, but negatively in the beech.

- After heat treatment, the yellow color change was found to be greater in the coniferous pine and fir wood than in the deciduous oak and beech.

- As a result of the heat treatment, the total color change value occurred in the pine, oak, fir, and beech, respectively.

- After the heat treatment, the alkaline bleaching solutions applied to the wood had a positive effect on the recovery of the natural color of the material. However, it was observed that the different color tones could have been formed due to the heterogeneous 


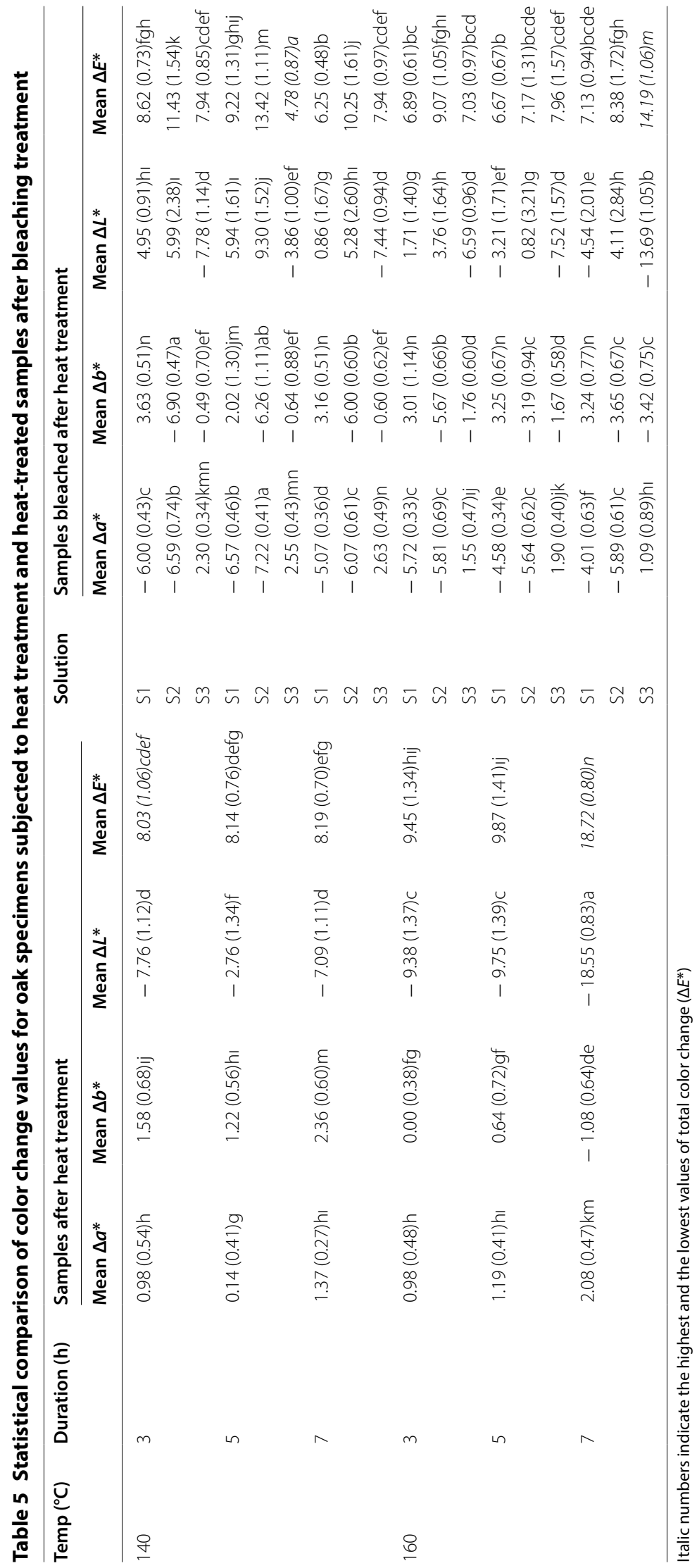




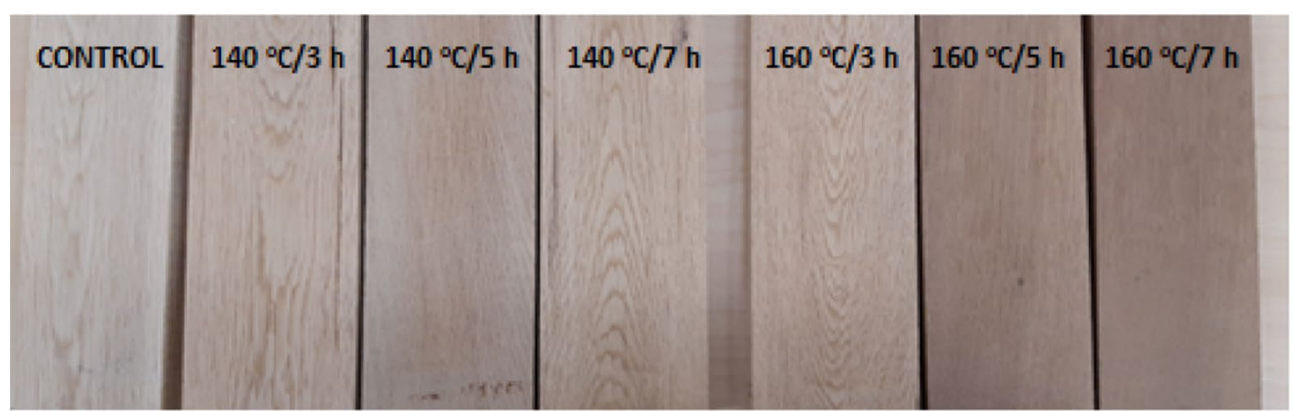

Fig. 8 Color change in oak after heat treatment
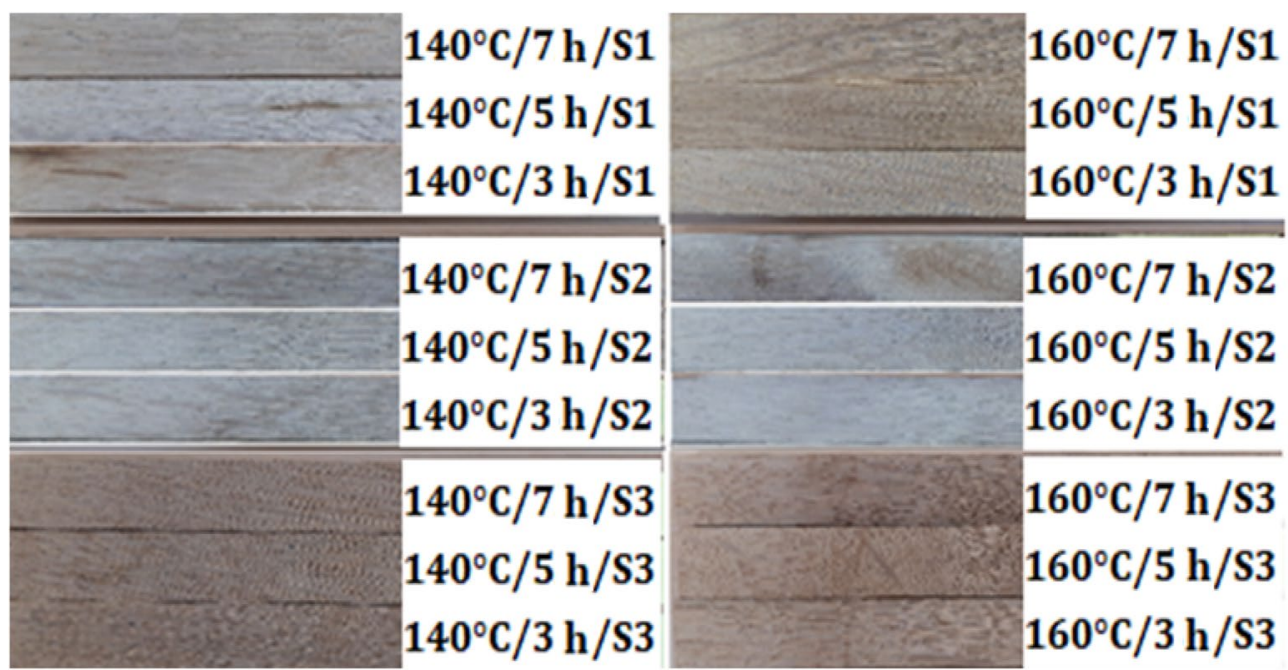

Fig. 9 Heat-treated oak samples after bleaching treatment

structure of the wood and the compounds found within it.

- The average total color change value of the Scots pine after heat treatment was determined as 15.93. As a result of the application of the S1 solution after heat treatment, the average total color change value of the Scots pine was 16.33, with the S2 solution 9.29, and with the S3 solution 17.93. Application of the S2 solution can be recommended to restore the natural color in heat-treated Scots pine wood.

- The average total color change in the fir after heat treatment was 8.7. As a result of the application of the $\mathrm{S} 1$ solution after heat treatment, the average total color change value in the fir was 9.08, with the S2 solution 5.8, and with the S3 solution 13.11. Application of the S2 solution can be recommended to restore the natural color in heat-treated fir wood.

- The average total color change value of the beech after heat treatment was 8.03. As a result of the application of the S1 solution after heat treatment, the average total color change value of the beech was 9.24, with the $\mathrm{S} 2$ solution 14.89, and with the S3 solution 6.8. Application of the S3 solution can be recommended to restore the natural color in heat-treated beech wood.

- The average total color change value of oak after heat treatment was 10.4. As a result of the application of the S1 solution after heat treatment, the average total color change value in the oak was 7.46, with the S2 solution 9.95, and with the S3 solution 8.32. Application of the S1 and S3 solutions can be recommended to restore the natural color in heattreated oak wood.

\section{Acknowledgements}

The authors would like to thank the personnel of Department of Wood Products Industrial Engineering of the Institute of Science at Duzce University.

\section{Authors' contributions}

MB designed and performed the experiments and analyzed the data. The heat treatment and bleaching process of wood materials carried out by MA. MA 
wrote the manuscript in consultation with MB. All authors read and approved the final manuscript.

\section{Funding}

Not applicable.

\section{Availability of data and materials}

All data generated or analyzed during this study are included in this published article.

\section{Competing interest}

The authors declare that they have no competing interests.

Received: 4 March 2020 Accepted: 17 September 2020

Published online: 29 September 2020

\section{References}

1. Sönmez A, Budakcı M (2004) Surface processes in woodworks. Gazi Publishing House Gazi University, Ankara ISBN: 975-97281-0-9(TK)

2. Budakçı M, Illçe AC, Gürleyen T (2011) Determining appropriate machine cutting properties and cutting theory criteria in processing different wooden and wood-based materials. Duzce University, Scientific Research Project Number: BAP 2009.03.01.024

3. Aydemir D, Gündüz G (2009) Effect of heat treatment on physical, chemical, mechanical and biological properties of the wood. Bartın For Eng J $15: 71-81$

4. Kocaefe D, Younsi R, Poncsak S, Kocaefe Y (2007) Comparison of different models for the high-temperature heat-treatment of wood. Int J Therm Sci 46:707-716

5. Korkut S, Kocaefe D (2009) The effect of heat treatment on the wood. Düzce Univ J For 5:11-14

6. Mayes D, Oksanen O (2002) Thermowood handbook. International ThermoWood Association, Unioninkatu 14, FIN-00130, Helsinki

7. Esteves B, Domingos IJ, Pereira HM (2008) Pine wood modification by heat treatment in air. BioResources 3:142-154

8. Boonstra MJA (2008) Two-stage Thermal modification of wood. Ph.D. Dissertation, Ghent University and Université Henry Poincaré, Ghent.

9. Yıldız S (2002) Physical, mechanical, technological and chemical properties of Fagus orientalis and Picea orientalis wood treated by heat. PhD Thesis, Karadeniz Technical University, Trabzon.

10. Ünsal O, Korkut S, Atik A (2003) The effect of heat treatment on some properties and colour in eucalyptus (Eucalyptus camaldulensis D.) wood. Maderas-Cienc Tecnol 2:145-152

11. Johansson D (2005). Strength and colour response of solid wood to heat treatment. PhD Thesis, Department of Skellefteå Campus, Division of Wood Technology, Luleå University of Technology, Luleå.

12. Sundqvist B (2002) Color response of Scots pine (Pinus sylvestris), Norway spruce (Picea abies) and birch (Betula pubescens) subjected to heat treatment in capillary phase. Holz als Roh- und Werkstoff 60(2):106-114

13. Sehlstedt-Persson M (2003) Colour responses to heat-treatment of extractives and sap from pine and spruce. Paper presented at the 8th International wood drying conference, Transilvania University of Brasov, Faculty of Wood Industry, Brasov, 25-29 August 2003

14. Tomak ED, Ustaomer D, Yildiz S, Pesman E (2014) Changes in surface and mechanical properties of heat treated wood during natural weathering. Measurement 53:30-39

15. Özçifçi A, Özbay G (2010) Impacts of bleaching chemicals and outdoor exposure on changes in the color of some varnished woods. BioResources 2:586-596

16. Liang T, Wang $L$ (2015) An environmentally safe and nondestructive process for bleaching birch veneer with peracetic acid. J Clean Prod 92:37-43

17. Yamamoto A, Rohumaa A, Hughes M, Vuorinen T, Rautkari L (2017) Surface modification of birch veneer by peroxide bleaching. Wood Sci Technol 1:85-89

18. Mononen K, Jääskeläinen AS, Alvila L, Pakkanen TT (2005) Chemical changes in silver birch (Betula pendula Roth) wood caused by hydrogen peroxide bleaching and monitored by color measurement (CIELab) and UV-Vis, FTIR and UVRR spectroscopy. Holzforschung 4:381-388

19. Budakçı M, Karamanoğlu M (2014) Effect of bleaching on hardness, gloss, and color change of weathered woods. BioResources 9:2311-2327

20. Cheumani-Yona AM, Budija F, Hrastnik D, Kutnar A, Pavlič M, Pori P, Petrič M (2015) Preparation of two-component polyurethane coatings from bleached liquefied wood. BioResources 10:3347-3363

21. TS 2470 (1976) Sampling methods for physical and mechanical experiments in the wood and its general properties. Turkish Standards Institution, Ankara

22. Demir M (1991) Inorganic chemistry and its practice. Inonu University Faculty of Science and Letters, Ankara

23. ASTM D 2224 (2003) Standard practice for calculation or color tolerances and color differences from instrumentally measured color coordinates. American Society For Testing and Materials, USA

24. Budakçi M, Korkut DS, Esen R (2010) The color changes on varnish layers after accelerated aging through the hot and cold-check test. Afr J Biotechnol 9:3595-3602

25. Sundqvist B, Karlsson O, Westermark U (2006) Determination of formicacid and acetic acid concentrations formed during hydrothermal treatment of birch wood and its relation to colour, strength and hardness. Wood Sci Technol 40:549-561

26. Tarvainen V, Saranpää P, Repola J (2001) Discoloration of Norway spruce and Scots pine timber during drying. Paper presented at the 7th International wood drying conference, Tsukuba, Japan, 9-13 July 2001

27. Bekhta P, Niemz P (2005) Effect of high temperature on the change in color, dimensional stability and mechanical properties of sprucewood. Holzforschung 57:539-546

28. Yaşar S (2009) Research on color changes resulting from heat treatment in calabrian pine extractives. Suleyman Demirel Univ Turk J For 1:95-100

29. Senol S, Budakçı M (2019) Effect of thermo-vibro-mechanic ${ }^{\circledR}$ densification process on the gloss and hardness values of some wood materials. BioResources 14:9611-9627

30. Kučerová V, Lagaňa R, Výbohová E, Hýrošová T (2016) The effect of chemical changes during heat treatment on the color and mechanical properties of fir wood. BioResources 11:9079-9094

31. Sahin HT, Arslan MB, Korkut S, Sahin C (2011) Colour changes of heattreated woods of red-bud maple, European hophornbeam and oak. Color Res Appl 36:462-466

32. Atar M (1999) Effects of bleaching chemicals on top surface treatment in the wooden materials. PhD Thesis, Institute of Science, Gazi University, Ankara.

33. Budakçı M, Çınar H (2004) Colour effects of stains on wood with knots, cracks and rots. Prog Org Coat 51:1-5

34. Budakçı M (2006) Effect of outdoor exposure and bleaching on surface color and chemical structure of scots pine. Prog Org Coat 56:46-52

35. Örs Y, Keskin H (2001) Wood material information. Atlas Publishing, İstanbul

36. Nuopponen M (2005) FT-IR and UV Raman spectroscopic studies on thermal modification of Scots pine wood and its extractable compounds. Ph.D. Dissertation, Helsinki University of Technology, Helsinki.

37. Mitsui K, Takada H, Sugiyama M, Hasegawa R (2001) Changes in the properties of light irradiated wood with heat treatment. Part 1. Effect of treatment conditions on the change in color. Holzforschung 55:601-605

38. Bekhta P, Niemz P (2003) Effect of high temperature on the change in color, dimensional stability and mechanical properties of spruce wood. Holzforschung 57:539-546

39. Esteves B, Velez MA, Domingos I, Pereira H (2008) Heat induced colour changes of pine (Pinus pinaster) and eucalypt (Eucalyptus globulus) wood. Wood Sci Technol 42:369-384

40. Čermák P, Dejmal A (2013) The effect of heat and ammonia treatment on colour response of oak wood (Quercus robur) and comparison of some physical and mechanical properties. Maderas Ciencia y tecnología 15:375-389

\section{Publisher's Note}

Springer Nature remains neutral with regard to jurisdictional claims in published maps and institutional affiliations. 